\title{
Environmental Control of Glycogen and Lipid Content of Mycobacterium phlei
}

\author{
By A. D. ANTOINE* AND B. S. TEPPER \\ Johns Hopkins-Leonard Wood Memorial Leprosy Research Laboratory, \\ Department of Pathobiology, School of Hygiene and Public Health, \\ Baltimore, Md. 21205, U.S.A.
}

(Accepted for publication 25 September 1968)

\begin{abstract}
SUMMARY
When the growth of surface cultures of Mycobacterium phlei was limited by nitrogen or sulphur, the organisms synthesized both glycogen and lipid as endogenous reserves. Equal weights of glycogen and lipid accumulated intracellularly which, combined, may account for $50 \%$ of the cell dry weight. Both storage materials also accumulated when growth was inhibited by chloramphenicol or $p$-fluorophenylalanine in otherwise nutritionally adequate media. In the absence of exogenous carbon substrate, the glycogen and lipid reserves were utilized as energy and carbon for nitrogen incorporation and continued growth. Evidence is presented which suggests that glycogen may be the preferred endogenous reserve in $M$. phlei.
\end{abstract}

\section{INTRODUCTION}

In their pioneer work on the physiology of the mycobacteria, Stephenson \& Whetham (1922, 1924) showed that, following depletion of glucose in growth media, Mycobacterium phlei utilized its stored lipids and the respiratory quotient, which had been $I \cdot I$ to $I \cdot 75$ during growth, fell to 0.8 . With the observation of the same phenomenon in M. tuberculosis (Andrejew, 1948), the generalization has been accepted that lipids serve as a reserve of carbon and energy in the mycobacteria. However, the demonstration of glycogen as a cell constituent in the avian (Chargaff \& Moore, 1944) and human tubercle bacilli (Kent \& Stacey, I949), and in $M$. phlei (German, Jones \& Nadarajah, I96r), suggests that the reserves may not be exclusively lipid. In addition, studies with $M$. phlei which have shown the simultaneous accumulation of equivalent amounts of lipid and carbohydrate during growth in nitrogen-limited media (Tepper, I965) also suggest that both substances may be reserves in this organism.

There is ample evidence that micro-organisms are able to utilize more than one material for endogenous metabolism (see Dawes \& Ribbons, 1964), but, usually in response to cultural or environmental conditions, a preferentially utilized reserve substrate is deposited. Different micro-organisms may store more than one reserve material. Escherichia coli (Dagley \& Johnson, 1953) and Rhodospirillum rubrum (Stanier, Doudoroff, Kunisawa \& Contopoulou, I959) have been reported to accumulate either glycogen-like polysaccharide or lipid; however, the particular reserve

* Present address: Department of Biology, McCollum-Pratt Institute, Johns Hopkins University, Baltimore, Md. 21218 , U.S.A. 
material deposited within the cell depended on the chemical nature of the carbon substrate. Recently, Damoglou \& Dawes (1967) were unable to confirm the accumulation of lipid in $E$. coli and found the lipid content to be essentially constant irrespective of the carbon source used for growth. Thus, the suggestion that both lipid and carbohydrate may be deposited as endogenous reserves in Mycobacterium phlei is of particular interest since these accumulations occur simultaneously under the same cultural conditions.

Storage material accumulation by micro-organisms has been extensively studied (for reviews see Herbert, I96I ; Dawes \& Ribbons, 1964) and it is known that conditions which restrict growth, but not the assimilation of the carbon source, favour accumulation of reserve substances. The present paper reports the effects of nutritional limitations and growth inhibitors on the accumulation of storage material by $\mathrm{Myco}$ bacterium phlei, and the extent to which lipid and carbohydrate, principally glycogen, serve as endogenous reserves in this organism.

\section{METHODS}

Cultivation. Mycobacterium phlei strain 72 was grown as a surface pellicle on media having the following basal composition per litre: potassium citrate, 2.0 g.; $\mathrm{MgSO}_{4} \cdot 7 \mathrm{H}_{2} \mathrm{O}, 0.6 \mathrm{~g}$.; $\mathrm{ZnSO}_{4} \cdot 7 \mathrm{H}_{2} \mathrm{O}, 25 \mathrm{mg}$.; $\mathrm{FeCl}_{3} \cdot 6 \mathrm{H}_{2} \mathrm{O}$, 0.I g.; $\mathrm{CoCl}_{2} \cdot 6 \mathrm{H}_{2} \mathrm{O}$, $2 \mathrm{mg}$.; $\mathrm{MnCl}_{2} \cdot 4 \mathrm{H}_{2} \mathrm{O}$, I mg.; $\mathrm{CaCl}_{2} \cdot 2 \mathrm{H}_{2} \mathrm{O}, 20 \mathrm{mg}$; anhydrous $\mathrm{K}_{2} \mathrm{HPO}_{4}$, 6.0 g.; final $\mathrm{pH} 7 \cdot 0$. Either L-asparagine $\mathrm{H}_{2} \mathrm{O}(3.0$ or $\mathrm{I} 2 \cdot 0 \mathrm{~g}$. $/ 1$.) or ammonium chloride $(2 \cdot \mathrm{I} 5$ or $8.6 \mathrm{~g} . / 1$.) served as the sole source of nitrogen $(\mathrm{N})$ in the growth media and represent 60 and $240 \mathrm{mg}$. N/100 ml. medium, respectively. Glycerol $(60 \mathrm{~g} . / 1$.) served as the major carbon source. The amounts of additional carbon supplied by asparagine were represented by molar equivalents of neutralized fumaric acid in the ammonium chloride medium. Media were dispensed in $100 \mathrm{ml}$. volumes in $250 \mathrm{ml}$. Erlenmeyer flasks and autoclaved for $\mathrm{I} 5 \mathrm{~min}$. at $\mathrm{I} 2 \mathrm{I}^{\circ}$. Cultures were incubated at $37^{\circ}$ and $60 \%$ relative humidity.

Medium exchange. Surface cultures were grown to the desired age and then medium exchanges were made according to the following procedure. The original medium was aseptically siphoned from the pellicle. The dropped pellicle was washed once by refloatation with basal medium, and then fresh medium of the desired composition was immediately added to refloat the pellicle. For these exchange experiments replicate cultures were used, some of which were removed for analysis at the time of exchange of medium while the remaining cultures were used, in duplicate, for exchange and subsequent incubations. The substrate concentrations used in the exchange experiments were as follows, per litre of basal medium: high nitrogen, $8.6 \mathrm{~g}$. $\mathrm{NH}_{4} \mathrm{Cl}$; low nitrogen, $2 \cdot 15 \mathrm{~g}$. $\mathrm{NH}_{4} \mathrm{Cl}$; and high carbon, $60.0 \mathrm{~g}$. glycerol. In the exchange studies where sulphates were omitted, the corresponding chloride salts were substituted in the basal medium.

Sampling. For estimation of surface growth, duplicate flasks were filtered through tared Sharkskin filter paper (Schleicher \& Schuell), washed with water, and dried to constant weight. For analytical determinations, bacteria were harvested by centrifugation, washed, lyophilized and stored over phosphorus pentoxide in a vacuum desiccator until ready for use. All cell analyses were conducted on pooled samples from two or more pellicles. 
Cell composition. Nitrogen content was determined by the micro-Kjeldahl digestion and colorimetric Nessler procedure described by Wilson \& Knight (I952). Total carbohydrates were determined by the anthrone method of Seifter, Dayton, Novic \& Muntwyler (1950). Glycogen was determined by the specific enzymic degradation and microdetermination method of Bueding \& Hawkins (1964). Lipids were extracted according to the method of Winder \& O'Hara (1962), evaporated under a stream of warm air, and weighed. Volatile and non-volatile fatty acids were isolated and separated by gas-chromatographic procedures by methods described by Saz \& Lescure (1966). Volatile fatty acids and fatty acid esters were tentatively identified by comparison of relative retention times with known fatty acids.

\section{RESULTS}

\section{Growth of Mycobacterium phlei}

Under the conditions of these experiments, all cultures had formed a thin pellicle on the surface of the medium by the third day and thereafter growth consisted in the thickening of this pellicle. In the cultures used for composition analyses (Table I), the third day was representative of the late exponential phase of growth and older cultures represented post-exponential growth. Unlike bacterial cultures which reach a maximum in incorporated nitrogen, post-exponential growth of pellicles of Mycobacterium phlei was characterized by a gradual increase in nitrogen content. This observation suggests that pellicles are composed of two types of bacterial population: a majority of organisms which have stopped growing and a lesser population, presumably in contact with the medium, which continues to divide.

Accumulation of storage materials. The relationship of storage material accumulation to the nitrogen concentration in the environment is shown in Table I. In all media tested, storage materials did not increase during exponential growth and the lipid, carbohydrate and glycogen of $M$. phlei remained constant at values determined by the nature and amount of the nitrogen source.

Maximal lipid and carbohydrate contents occurred during post-exponential growth in nitrogen-limited media (Table 1 ). The highest contents were reached in the nitrogenlimited asparagine medium with lipid at $24.4 \%$ and carbohydrate at $36.6 \%$ of the dry wt of the bacteria; glycogen represented $64 \%$ of the carbohydrate fraction. In both nitrogen-limited media the greatest increase in cell constituents was observed in the carbohydrate fraction. Maximal pellicle weights were produced during the period of maximal lipid and carbohydrate synthesis.

When the nitrogen concentration of the medium was increased fourfold, there were essentially no changes in the lipid and carbohydrate contents during growth (Table I). Lipid contents differed for bacteria grown in the two media but remained constant at $12 \%$ in the asparagine medium and $18 \%$ in the ammonia medium; carbohydrate was approximately $12 \%$ of the dry wt of bacteria from both media. Glycogen was present in these bacteria, but represented only $\mathrm{I} \cdot 5$ to $4.0 \%$ of the pellicle weight.

Nitrogen concentrations of $120 \mathrm{mg}$. were also found to be nitrogen-limiting and resulted in constituent amounts intermediate to those at 60 and $240 \mathrm{mg}$. N. The composition of bacteria grown in media containing $480 \mathrm{mg}$. N. was identical to those grown on $240 \mathrm{mg}$. $\mathrm{N}$.

Under the conditions of these experiments, the composition of Mycobacterium 
phlei from nitrogen-excess media, throughout growth, resembled the composition of these bacteria during exponential growth in all media. Their lipid and carbohydrate content can be considered to be the minimal values essential for cell structure and metabolism which are produced during optimal pellicle growth. Contents of lipid and glycogen above these amounts apparently represent non-essential endogenous reserves.

Nature of the storage materials. In these analyses the major component of the carbohydrate fraction which accumulated during growth on nitrogen-limited media was glycogen. The possibility that lesser components of the carbohydrate fraction may also serve as endogenous reserves is presently under investigation. Glycogens have been isolated from Mycobacterium phlei and characterized; the results will be reported separately.

Table I. Yields of organisms and storage material content of Mycobacterium phlei grown on nitrogen-limited and nitrogen-excess media

\begin{tabular}{|c|c|c|c|c|c|c|}
\hline \multirow[b]{2}{*}{$\begin{array}{l}\text { Growth medium } \\
\text { Nitrogen-limited (60 mg. } \\
\text { N/I00 ml. medium) }\end{array}$} & \multirow[b]{2}{*}{$\begin{array}{l}\text { Age } \\
\text { (days) }\end{array}$} & \multicolumn{2}{|c|}{ Yield } & \multicolumn{3}{|c|}{ Constituents } \\
\hline & & $\begin{array}{l}\text { Dry wt } \\
\text { (mg./ } \\
\text { I00 ml. } \\
\text { culture) }\end{array}$ & $\begin{array}{l}\text { Nitrogen } \\
\text { (mg./ } \\
100 \mathrm{ml} . \\
\text { culture ) }\end{array}$ & $\begin{array}{l}\text { Lipid } \\
(\mathrm{mg} . / \mathrm{mg} \\
\text { cell } \mathrm{N})\end{array}$ & $\begin{array}{l}\text { Carbo- } \\
\text { hydrate } \\
\text { (mg./mg. } \\
\text { cell N) }\end{array}$ & $\begin{array}{l}\text { Glycogen } \\
(\mathrm{mg} / \mathrm{mg} . \\
\text { cell } \mathrm{N})\end{array}$ \\
\hline Asparagine & $\begin{array}{l}0 \\
3 \\
5 \\
7 \\
9\end{array}$ & $\begin{array}{r}\text { I } \\
74 \\
257 \\
1010 \\
1325\end{array}$ & $\begin{array}{r}<0.1 \\
5.8 \\
19.8 \\
38.4 \\
39.8\end{array}$ & $\begin{array}{l}I \cdot 7 \\
I \cdot 6 \\
I \cdot 8 \\
6 \cdot 4 \\
8 \cdot 0\end{array}$ & $\begin{array}{r}2 \cdot 3 \\
2 \cdot 2 \\
2 \cdot 5 \\
9 \cdot 0 \\
12 \cdot 2\end{array}$ & $\begin{array}{l}0.9 \\
0.9 \\
I \cdot 0 \\
6 \cdot I \\
8 \cdot I\end{array}$ \\
\hline Ammonia & $\begin{array}{l}0 \\
3 \\
5 \\
7 \\
9\end{array}$ & $\begin{array}{r}1 \\
196 \\
711 \\
907 \\
877\end{array}$ & $\begin{array}{r}<0.1 \\
I 7 \cdot I \\
39 \cdot 8 \\
46.3 \\
43 \cdot 0\end{array}$ & $\begin{array}{l}I \cdot 4 \\
I \cdot 4 \\
3 \cdot 4 \\
4 \cdot 2 \\
4 \cdot 5\end{array}$ & $\begin{array}{l}0.9 \\
0.9 \\
4.5 \\
4.3 \\
4.1\end{array}$ & $\begin{array}{l}0 \cdot 2 \\
0 \cdot 2 \\
2 \cdot 4 \\
2 \cdot 2 \\
2 \cdot 2\end{array}$ \\
\hline $\begin{array}{l}\text { Nitrogen-excess (240 mg. } \\
\mathrm{N} / 100 \mathrm{ml} . \text { medium) }\end{array}$ & & & & & & \\
\hline Asparagine & $\begin{array}{l}0 \\
3 \\
5 \\
7 \\
9\end{array}$ & $\begin{array}{r}1 \\
78 \\
541 \\
1528 \\
2072\end{array}$ & $\begin{array}{r}<0.1 \\
6.5 \\
44.4 \\
122.2 \\
178.2\end{array}$ & $\begin{array}{l}I \cdot 4 \\
I \cdot 4 \\
I \cdot 4 \\
I \cdot 5 \\
0.8\end{array}$ & $\begin{array}{l}I \cdot 4 \\
I \cdot 4 \\
I \cdot 5 \\
I \cdot 5 \\
I \cdot I\end{array}$ & $\begin{array}{l}0.5 \\
0.5 \\
0.5 \\
0.6 \\
0.2\end{array}$ \\
\hline Ammonia & $\begin{array}{l}0 \\
3 \\
5 \\
7 \\
9\end{array}$ & $\begin{array}{r}I \\
100 \\
685 \\
I 236 \\
I 523\end{array}$ & $\begin{array}{r}<0 . I \\
9 . I \\
60.3 \\
100 . I \\
I 23.4\end{array}$ & $\begin{array}{l}2 \cdot 0 \\
2 \cdot I \\
I \cdot 9 \\
2 \cdot 2 \\
2 \cdot 3\end{array}$ & $\begin{array}{l}I \cdot 2 \\
I \cdot 2 \\
I \cdot 4 \\
I \cdot 6 \\
I \cdot 2\end{array}$ & $\begin{array}{l}0.2 \\
0.2 \\
0.2 \\
0.5 \\
0.2\end{array}$ \\
\hline
\end{tabular}

The fatty acids in lipid extracts from exponentially growing Mycobacterium phlei (I5\% lipid content) and after post-exponential accumulation ( $22 \%$ lipid content) were separated by gas-chromatographic procedures and quantitated. No single fatty acid accounted for the accumulation of lipid (Table 2). There was a general increase in all fatty acids from $C_{1}$ to $C_{18}$, with the greatest increases in the $C_{14}$ to $C_{18}$ acids. Experiments are in progress to determine whether the stored lipids occur as free acids, glycerides or complex lipids in M.phlei. Other lipids, especially the hydroxylated and branched chain fatty acids which were not determined in this study, may also accumulate. 


\section{Medium exchange experiments}

In contrast to the gradual modifications in the nutritional environment which result during growth, the medium exchange procedure exposes bacteria of known composition, uniformly and abruptly to controlled environmental changes. This procedure was undertaken to define more accurately the factors which regulate storage material synthesis and to study the utilization of the lipid and glycogen endogenous reserves.

\section{Table 2. Fatty-acid content of Mycobacterium phlei at different values of lipid accumulation}

Fatty acids in lipid extracts of Mycobacterium phlei (20 mg. cell N) were separated by gas-chromatographic procedures. Contents are expressed as peak areas $\left(\mathrm{cm}^{2}\right)$ of fatty acids in the original lipid extracts.

Fatty acid

Acetic
Propionic
Isobutyric
Butyric
a-Methylbutyric
Caproic
Caprylic
Capric
Lauric
Myristic
Myristoleic
Palmitic
Palmitoleic
Stearic
Oleic
Linoleic

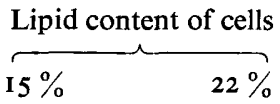

$\begin{array}{rr}34 & 52 \\ 7 & 14 \\ 4 & 11 \\ 3 & 2 \\ 2 & 4 \\ 4 & 26 \\ 312 & 468 \\ 96 & 128 \\ 20 & 110 \\ 228 & 1292 \\ 30 & 165 \\ 1062 & 6726 \\ 153 & 2142 \\ 224 & 1120 \\ 392 & 5292 \\ 204 & 1326\end{array}$

Accumulation of storage materials. Table 3 records experiments in which pellicles of Mycobacterium phlei containing minimal amounts of lipid and glycogen were exchanged to modified environments. Cultures incubated on the initial growth medium, with and without exchange, served as controls. Exchange to the low nitrogen, high carbon medium resulted in an increase in the pellicle weight, but when the added nitrogen was utilized and nitrogen again became limiting, increases in the lipid, carbohydrate and glycogen occurred. The highest values of accumulation occurred when pellicles were incubated on a nitrogen-free, high-carbon medium. The increases in pellicle weight could be accounted for by the accumulation of lipid and carbohydrate. The increases in carbohydrate values were essentially due to glycogen accumulation. It is of particular importance that the rate and amount of glycogen accumulation exceeds that of lipid accumulation. At day 5 the combined lipid and carbohydrate fractions represented approximately $50 \%$ of the pellicle wt of bacteria exchanged to the nitrogen-free high-carbon medium. When a high nitrogen carbon-free medium replaced the original growth medium, pellicle weights remained essentially constant, with slight decreases in the constituent amounts.

Effect of other methods of growth inhibition. In nitrogen-limited media, the depletion of exogenous nitrogen may stop protein synthesis but not protein turnover. 


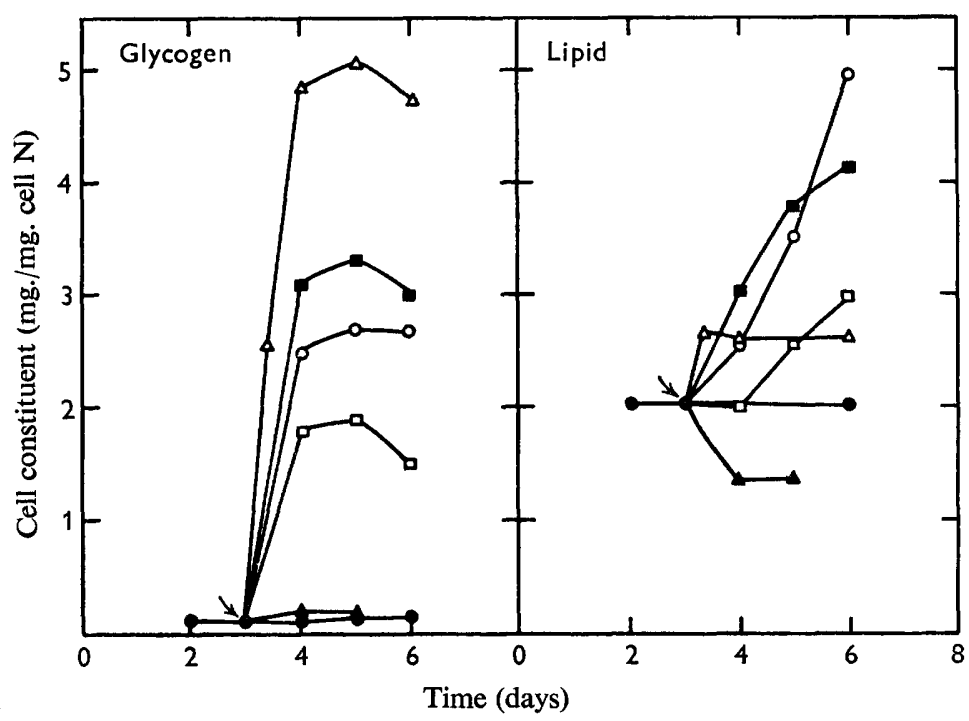

Fig. I. Effect of sulphur deficiency and inhibitors of protein synthesis on the accumulation of glycogen and lipid in Mycobacterium phlei. Medium exchanges were made at the time indicated by the arrows. $\bullet$, Unchanged control, high nitrogen, high carbon medium; $\triangle$, exchanged to sulphate-deficient, high-nitrogen, high-carbon medium; $O$, exchanged to high-nitrogen, high-carbon medium containing chloramphenicol ( $100 \mu \mathrm{g} . / \mathrm{ml}$.$) ; \square$, exchanged to highnitrogen, high-carbon medium containing $p$-fluorophenylalanine (100 $\mu \mathrm{g} . / \mathrm{ml}$.); $\boldsymbol{\Delta}$, exchanged to high-nitrogen, high-carbon medium containing 2,4 -dinitrophenol ( $100 \mu \mathrm{g}$. $/ \mathrm{ml}$.); a, exchanged to no-nitrogen, high-carbon medium.

\section{Table 3. Effect of nitrogen and carbon concentration on the accumulation of storage materials in Mycobacterium phlei}

Replicate cultures of Mycobacterium phlei were grown as pellicles on the high-nitrogen high-carbon medium. Medium exchanges (see Methods) were made at day 3. Duplicate cultures were harvested for analysis at the time of medium exchange and following the additional incubation of cultures exchanged to modified media. Unchanged cultures served as normal growth controls. Results represent the average composition of the duplicate cultures.

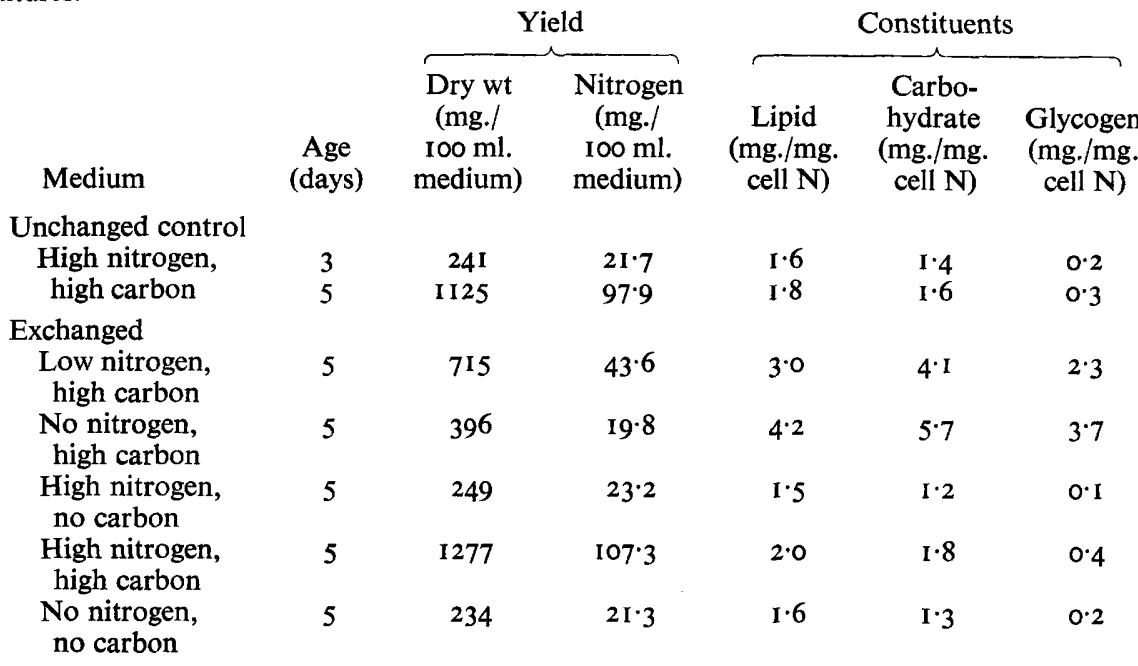


Chloramphenicol and p-fluorophenylalanine are substances which inhibit both protein synthesis and protein turnover more directly; when bacteria were incubated on the high nitrogen, high-carbon medium in the presence of chloramphenicol and $p$-fluorophenylalanine both glycogen and lipid accumulated (Fig. I). Chloramphenicol inhibited growth, and the amounts of glycogen and lipid were comparable to accumulations in nitrogen-limited cultures. The rates and amounts of accumulation from $p$-fluorophenylalanine inhibition were lower than the nitrogen-deficient controls since the $p$-fluorophenylalanine concentration used (100 $\mu \mathrm{g}$./ml.) resulted in only $40 \%$ inhibition of growth. The addition of 2,4-dinitrophenol to high-nitrogen, high-carbon media resulted in complete inhibition of growth and glycogen accumulation and a decrease in the lipid content of the bacteria.

Sulphur-deficiency also provides a potential inhibitor of protein synthesis, as well as limiting co-factors of storage material syntheses such as glutathione, cysteine, and coenzyme A. Sulphur-limited Escherichia coli do not accumulate glycogen, presumably because of co-factor deficiencies (Holme \& Palmstierna, 1956 b), while Aerobacter aerogenes strains may accumulate glycogen to 50 to $100 \%$ of values achieved in nitrogen-limited cultures (Segel, Cattaneo \& Sigal, 1965). The reason for this difference is unknown. In Mycobacterium phlei, sulphur-deficient growth conditions stimulated glycogen accumulation to higher levels than those produced by nitrogendeficiency (Fig. I). Lipid also accumulated, but not to the same extent as the nitrogenlimited controls.

These results demonstrate that other methods of growth inhibition besides nitrogendepletion can also result in storage material accumulation, provided the inhibition does not interfere with carbon-substrate utilization or the energy metabolism of the cell. These studies also suggest that the glycogen and lipid-synthesizing enzymes present at the time of addition of inhibitor were sufficient to participate in the subsequent accumulations.

Utilization of storage materials. Evidence for the utilization of stored lipid and glycogen for energy and as the source of carbon for the synthesis of nitrogenous cell constituents is shown in Table 4. When pellicles of Mycobacterium phlei containing stored lipid and glycogen were exchanged to a high-nitrogen medium without added carbon substrate, growth continued and the lipid and glycogen contents were decreased to minimal values. Pellicle weight did not decrease with the depletion of lipid and glycogen stores, but increased $5 \%$ over the weight at the time of exchange. The accompanying $42.5 \%$ increase in total pellicle nitrogen is highly significant. In the absence of exogenous carbon, only the stored lipid and glycogen could supply the energy and carbon for the incorporation of this nitrogen into cellular constituents. These observations show therefore that the stored lipids and glycogen can serve as a reserve of carbon, as well as energy, for the assimilation of exogenous nitrogen.

The results of the exchange to the low-nitrogen, high-carbon medium (Table 4) are also of particular significance because they show that, in Mycobacterium phlei, glycogen is a more labile storage material than lipid and is utilized before lipid. The replenishment of exogenous nitrogen on exchange to this medium allowed additional growth, as with the high-nitrogen medium, with a resultant decrease in carbohydrate and glycogen at day $4 \cdot 5$. When exogenous nitrogen again became limiting, glycogen was subsequently resynthesized. During this period, when glycogen was partially utilized and then resynthesized, the lipid content remained constant. Similarly, 
exchange to the high-nitrogen, high-carbon medium depleted glycogen stores but only partially decreased the lipid content. This response suggests that glycogen synthesis is more readily regulated by the nutritional environment than lipid synthesis.

\title{
Table 4. Effect of nitrogen and carbon concentration on the storage materials accumulated by Mycobacterium phlei
}

\begin{abstract}
Replicate cultures of Mycobacterium phlei were grown as pellicles on the low nitrogen, high carbon medium. Medium exchanges (see Methods) were made at day 4. Duplicate cultures were harvested for analysis at the time of medium exchange and following the additional incubation of cultures exchanged to modified media. Unchanged cultures served as normal growth controls. Results represent the average composition of the duplicate cultures.
\end{abstract}

\begin{tabular}{|c|c|c|c|c|c|c|}
\hline \multirow[b]{2}{*}{ Medium } & \multirow[b]{2}{*}{$\begin{array}{c}\text { Age } \\
\text { (days) }\end{array}$} & \multicolumn{2}{|c|}{ Yield } & \multicolumn{3}{|c|}{ Constituents } \\
\hline & & $\begin{array}{l}\text { Dry wt } \\
\text { (mg./ } \\
\text { Ioo ml. } \\
\text { medium) }\end{array}$ & $\begin{array}{l}\text { Nitrogen } \\
\text { (mg./ } \\
\text { I00 ml. } \\
\text { medium) }\end{array}$ & $\begin{array}{c}\text { Lipid } \\
\text { (mg./mg. } \\
\text { cell } \mathrm{N} \text { ) }\end{array}$ & $\begin{array}{c}\text { Carbo- } \\
\text { hydrate } \\
\text { (mg./mg. } \\
\text { cell N) }\end{array}$ & $\begin{array}{c}\text { Glycogen } \\
\text { (mg./mg. } \\
\text { cell N) }\end{array}$ \\
\hline \multicolumn{7}{|c|}{ Unchanged control } \\
\hline $\begin{array}{l}\text { Low nitrogen, } \\
\text { high carbon }\end{array}$ & $\begin{array}{l}4 \\
5\end{array}$ & $\begin{array}{l}583 \\
871\end{array}$ & $\begin{array}{l}33 \cdot 2 \\
43 \cdot 6\end{array}$ & $\begin{array}{l}3 \cdot 0 \\
3 \cdot 8\end{array}$ & $\begin{array}{l}5 \cdot 3 \\
6 \cdot 3\end{array}$ & $\begin{array}{l}3 \cdot I \\
3 \cdot 8\end{array}$ \\
\hline \multicolumn{7}{|l|}{ Exchanged } \\
\hline $\begin{array}{l}\text { High nitrogen, } \\
\text { no carbon }\end{array}$ & 5 & 623 & $47 \cdot 3$ & $r \cdot 7$ & $2 \cdot 0$ & 0.3 \\
\hline $\begin{array}{l}\text { Low nitrogen, } \\
\text { high carbon }\end{array}$ & $\begin{array}{l}4 \cdot 5 \\
5\end{array}$ & $\begin{array}{r}859 \\
\text { II } 23\end{array}$ & $\begin{array}{l}52 \cdot 9 \\
6 \mathrm{r} \cdot 8\end{array}$ & $\begin{array}{l}3 \cdot 0 \\
3 \cdot 8\end{array}$ & $\begin{array}{l}3 \cdot 7 \\
4 \cdot 8\end{array}$ & $\begin{array}{l}1 \cdot 7 \\
2 \cdot 5\end{array}$ \\
\hline $\begin{array}{l}\text { High nitrogen, } \\
\text { high carbon }\end{array}$ & 5 & 1067 & $83 \cdot 2$ & $2 \cdot 4$ & $1 \cdot 9$ & 0.4 \\
\hline $\begin{array}{l}\text { No nitrogen, } \\
\text { no carbon }\end{array}$ & 5 & 588 & $32 \cdot 3$ & $2 \cdot 8$ & $5 \cdot 3$ & $2 \cdot 9$ \\
\hline $\begin{array}{l}\text { No nitrogen, } \\
\text { high carbon }\end{array}$ & 5 & 763 & $37 \cdot 4$ & $4 \cdot 2$ & $6 \cdot 1$ & $3 \cdot 7$ \\
\hline
\end{tabular}

Studies of the lipids and polysaccharides of mycobacteria have mainly been concerned with the chemistry of the compounds found in these organisms, with little attention given to their physiological significance. This report has demonstrated that, in Mycobacterium phlei, the synthesis and accumulation of classes of lipid and polysaccharide are controlled by modifications in the nutritional environment and that these stored materials serve as endogenous reserves of carbon and energy in the absence of exogenous carbon substrate.

The lipid and carbohydrate content of Mycobacterium phlei were minimal during exponential growth in nitrogen-limited cultures but increased enormously during the post-exponential phase. The combined stored materials may accumulate to as much as $50 \%$ of the cell weight. Since storage materials do not accumulate during growth in nitrogen-excess media, it would appear that the synthesis of these reserves is largely controlled by the nitrogen concentration in the environment. In this respect, storagematerial synthesis in $M$. phlei resembles synthesis of glycogen in Escherichia coli (Holme \& Palmstierna, I956a) and Aerobacter aerogenes (Segel et al. 1965), poly- $\beta$ hydroxybutyrate in Bacillus megaterium (Macrae \& Wilkinson, 1958), and lipids in the yeasts Rhodotorula gracilis, R. glutinis and Lipomyces starkeyi (reviewed by Mulder, Deinema, Van Neen \& Zevenhuizen, 1962). When grown on nitrogen-limiting media 
these organisms only accumulate one reserve substance, but they may synthesize other reserves under different cultural and environmental conditions (see Dawes \& Ribbons, 1964). In contrast, $M$. phlei has been found to synthesize and accumulate both lipid and glycogen when growth was inhibited by nitrogen depletion and by antibiotics.

The means by which growth inhibition controls storage material synthesis is uncertain. However, the data with Mycobacterium phlei are consistent with the hypothesis that conditions which favour accumulation of reserves appear to be conditions of ' uncoupled growth', conditions under which energy is produced at a rate faster than needed (Segel et al. 1965). The synthesis of storage materials may be considered a shunt mechanism by which some of this excess energy may be conserved intracellularly.

For these stored materials to be considered as endogenous reserves, their function as a source of energy and carbon must be demonstrated. In Escherichia coli, glycogen has been found to serve as a source of carbon for the synthesis of nitrogenous cell constituents (Holme \& Palmstierna, 1956c). In Mycobacterium phlei, stored glycogen and lipid can be utilized as a carbon source for continued growth. When bacteria with stored glycogen and lipid are offered a nitrogen substrate in the absence of exogenous carbon, the depletion of glycogen and lipid is accompanied by a marked increase in incorporated nitrogen. Since no other carbon substrate was present, energy for nitrogen assimilation and the carbon skeletons for the synthesis of nitrogenous cell constituents could only be derived from these reserves. These growth experiments have also shown that, although glycogen and lipid stores are synthesized concurrently, glycogen may be utilized preferentially, and at least partially depleted, before lipid utilization is initiated. The regulatory mechanism which permits this differential utilization provides a perplexing problem for further investigation.

We are indebted to $\mathrm{E}$. Bueding and $\mathrm{H}$. Saz for suggestions made during this investigation. The preservative-free chloramphenicol was generously provided by Parke, Davis and Co.

This investigation was supported by Public Health Service Training grant AI-220 and Public Health Service grant AI-06944 from the National Institute of Allergy and Infectious Diseases.

\section{REFERENCES}

ANDREJEW, A. (1948). L'utilisation par oxydation de quelques substances azotées par le bacille de Koch. Annls Inst. Pasteur 74, 464.

BuEDING, E. \& HAwkins, J. T. (1964). Enzymic degradation and microdetermination of glycogen. Analyt. Biochem. 7, 26.

Chargaff, E. \& MOore, D. H. (1944). On bacterial glycogen: the isolation from avian tubercle bacilli of a polyglucosan of very high molecular weight. J. biol. Chem. $\mathbf{r 5 5}, 483$.

DAGLEY, S. \& JoHNSON, A. R. (1953). The relation between lipid and polysaccharide contents of Bact. coli. Biochim. biophys. Acta $1 \mathrm{II}, \mathrm{I} 58$.

DAMOGLOU, A. P. \& DAwES, E. A. (1967). Studies on the lipid content and phosphate requirement of glucose- and acetate-grown Escherichia coli. Biochem. J. 102, $37 \mathrm{P}$.

Dawes, E. A. \& RibBons, D. W. (1964). Some aspects of the endogenous metabolism of bacteria. Bact. Rev. 28, 126.

German, R. J., Jones, A. S. \& Nadarajah, M. (1961). Polysaccharides of Mycobacterium phlei. Nature, Lond. 189, 1008. 
HerberT, D. (1961). The chemical composition of microorganisms as a function of their environment. Symp. Soc. gen. Microbiol. II, 39I.

Holme, T. \& PALmSTIERNA, H. (1956a). Changes in glycogen and nitrogen-containing compounds in Escherichia coli в during growth in deficient media. I. Nitrogen and carbon starvation. Acta chem. scand. 10, 578 .

Holme, T. \& PALMSTIERNA, H. (1956b). Changes in glycogen and nitrogen-containing compounds in Escherichia coli B during growth in deficient media. II. Phosphorus and sulfur starvation. Acta chem. scand. I0, 1553 .

Holme, T. \& Palmstierna, H. (1956c). On the glycogen in Escherichia coli B; its synthesis and breakdown and its specific labelling with ${ }^{14} \mathrm{C}$. Acta chem. scand. 10, 1557.

Kent, P. W. \& StaceY, M. (1949). Studies on the glycogen of $M$. tuberculosis (human strain). Biochim. biophys. Acta 3, 64I.

MACRAE, R. M. \& WILKINSON, J. F. (1958). The influence of cultural conditions on poly- $\beta$-hydroxybutyrate synthesis in Bacillus megaterium. Proc. R. phys. Soc. Edinb. A 27, 73.

Mulder, E. G., Deinema, M. H., Van Neen, W. L. \& ZeVenhuizen, L. P. T. M. (I962). Polysachcharides, lipids and poly- $\beta$-hydroxybutyrate in micro-organisms. Rec. Trav. Chim. 8r, 797.

SAZ, H. J. \& LESCURE, O. L. (1966). Interrelationships between the carbohydrate and lipid metabolism of Ascaris lumbricoides egg and adult stages. Comp. Biochem. Physiol. 18, 845.

Segel, I. H., Cattaneo, J. \& Sigal, N. (1965). The regulation of glycogen synthesis in Aerobacter aerogenes. In Colloques internationaux de C.N.R.S., Mécanismes de régulation des activités cellulaires chez les microorganismes, 1963. p. 337. Paris: Centre National de la Recherche Scientifique.

Seifter, S., Dayton, S., Novic, B. \& Muntwyler, E. (1950). The estimation of glycogen with anthrone reagent. Archs Biochem. 25, 19 I.

Stanier, R. Y., Doudoroff, M., Kunisawa, R. \& Contopoulou, R. (1959). The role of organic substrates in bacterial photosynthesis. Proc. natn. Acad. Sci. U.S.A. 45, I246.

Stephenson, M. \& Whetham, M. D. (I922). Studies in the fat metabolism of the timothy grass bacillus. Proc. R. Soc. B 93, 262.

Stephenson, M. \& Whetham, M. D. (1924). Studies in the fat metabolism of the timothy grass bacillus. II. The carbon balance-sheet and respiratory quotient. Proc. R. Soc. B 95, 200.

TEPPER, B. S. (1965). Modification of cellular constituents during growth of Mycobacterium phlei. Am. Rev. resp. Dis. 92, 75.

Wilson, P. W. \& KNIGHT, S. G. (1952). Experiments in Bacterial Physiology, p. 55. Minneapolis: Burgess Publ. Co.

WindeR, F. G. \& O'HARA, C. (1962). Effects of iron deficiency and of zinc deficiency on the composition of Mycobacterium smegmatis. Biochem. J. 82, 98. 